\title{
POLYPHONY IN ORIGINAL WORKS FOR BANDURA
}

\section{Svitlana Shchitova ${ }^{1}$}

DOI: https://doi.org/10.30525/978-9934-26-001-8-3-3

Abstract. The article is aimed at analyzing a number of original polyphonic works for bandura in various genres, belonging to a leading composer of the Dnieper region, Honored Artist of Ukraine Valentina Martyniuk. Published in the form of a textbook composer «Ukrainian song in polyphonic works for bandura», these works are in great demand among performers, pupils, students and teachers of all levels of education. They are often heard in concert programs, competitions and festivals. This fact is due to the appeal to polyphonic bandura works as self-sufficient original compositions, which organically combined many ways of counterpoint technique and the latest compositional techniques with authentic folklore material or national song melody. This organic synthesis was achieved thanks to the high professional level of the master in collaboration with the famous representative of the bandura school Svitlana Ovcharova. It was such a creative union that contributed to the most comfortable, natural sound of the bandura; Deprived of the vocal voice of her performer, she absorbs the vocals from the song as the foundation of each play. Thus, the instrument seems to replace the words of the song with a purely instrumental sound. But the words are read in every polyphonic play by V. Martyniuk. It is noteworthy that the composer expands the «range» of polyphonic genres and combines technically simple, more traditional inventions with cyclical works, which do not follow certain canons and uses a wide range of possible genre combinations - chorale and fugue, fantasy, fugue and epilogue, fugue and kolomyyka, etc. Such compositions deploy a contrasting material that requires both greater alignment and the achievement of a true concert performance style. The performer has a difficult task - to convey the content of the song, to get into its features and, using polyphonic techniques and appropriate technical capabilities, to create a three-dimensional image that is significant and bring it to the listener. So, the analysis of stylistic and constructive-logical regularities

\footnotetext{
${ }^{1} \mathrm{PhD}$ in Arts, Associate Professor, Head of the Department «History and Theory of Music», M. Glinka Dnipropetrovsk Academy of Music, Ukraine.

(C) Svitlana Shchitova
} 
of the structure of polyphonic works for bandura-solo by modern composer V. Martyniuk is made to help a young musician who learns the science of performing polyphony and seeks not only to improve his professional skills, but also to preserve and promote his national culture. The combination of the timbre of the bandura, as a symbol of the soul of the Ukrainian people, with folk songs and pan-European polyphonic traditions can further contribute to the realization of a truly national identity. The project of creating a self-sufficient, artistically original, nationally original polyphonic repertoire for the bandura is unfolding; next year it is planned to republish the collection «Ukrainian song in polyphonic works for bandura» (second edition) with the addition of new polyphonic works by V. Martyniuk and their performance-theoretical analysis.

\section{Introduction}

At the present stage in the world musical culture the understanding of bandura as an instrument of folklore origin, identical to the Ukrainian national mentality, is preserved. At the same time, in the repertoire policy of the bandura there are many new, original works, which combine the folklore nature of the origin of the instrument, and modern composer's findings in many genre models. Between the growth of professional performance and the emergence of new compositions there is a certain interdependent process.

Among those who are trying to find new techniques, to reveal the hidden qualities of the bandura's sound production, to present it in an updated form is Valentyna Martyniuk one of the leading composers of Ukraine, Honored Cultural Worker of Ukraine. In creative collaboration with Svitlana Ovcharova, Honored Worker of Culture of Ukraine, Artistic Director of the Laureate of the All-Ukrainian and International Competitions of the Bandura Band «Charivnytsia» (Dnipro), she created original vocal and instrumental compositions, including polyphonic pieces. Continuing the national traditions, they expand the concert-pedagogical repertoire of the instrument and expand the panorama of the Ukrainian polyphonic style, «which has well-defined formal features that reflect the peculiarities of the national (Ukrainian) mentality-thinking. In a generalized universal sense, it corresponds to the concepts of national (Ukrainian) music, as well as Ukrainian polyphony» [6, p. 85-86].

It should be noted that the bandura used to attract the Dnipropetrovsk composer as an accompanying instrument in solo singing, practically 
squeezing out the traditional piano («Little Ukrainian», «Taras Shevchenko», «Lullaby Maria», «Here is my soul», «Dole, dolenko moya»). «Come back, Cossack», «Fly, my swallow»), and ensemble in chamber and instrumental works («Cuckoo of Time» for bandura ensemble, flute, cello and drums, «Con moto» (for bandura quartet), and solo («Ariadne's thread», «Allusions to the Ukrainian folk theme», «Fantasy on the Ukrainian theme», «Farewell melody», «Rain, wormwood»).

The composer reveals all the features of her creative handwriting in polyphonic pieces for solo bandura created in recent years: Invention (2009), Choral and Fugue (2009), Prelude and Fugue (2012), Fugue and Postlude (2013), Fantasy, Fugue and epilogue (2016), Fugue with a kolomyyka (2017), Four inventions on the themes of Cossack songs of Dnipropetrovsk region (2017).

\section{Folklore basis in inventions for bandura}

The significance of V. Martyniuk's polyphonic works is quite great, because very few original polyphonies were created for the bandura:

- R. Hrynkiv Fugue-ostinato in c minor;

- M. Dremlyuga Invention and two polyphonic cycles;

- V. Tylyk Prelude «Memory», Fugue «Wild Steppe», a fragment from the suite «Confession of Magic Strings»;

- E. Yutsevich Prelude and fugue in a-moll.

However, the bandura players appeal to the original polyphonic music became relevant and extremely necessary, because the translations of polyphonic works by D. Scaralatti, G. Handel, I. Bach, intended for keyboard instruments, do not fully meet the capabilities of the bandura and therefore do not reach the highest artistic level, congenial to the originals.

Polyphonic bandura works by V. Martyniuk are a page inscribed in the phenomenon of «Ukrainian polyphony» - «a branch of musical art, which corresponds to the general technological (stylistic) principles of polyphonic forms and genres, at the same time marked by specific national features» $[6$, p. 23].

Such attention to polyphony testifies not only to the urgent need of the performers' own bandura polyphony. For the composer, immersion in various well-known polyphonic forms and genres fits into the «polyphony of creative consciousness [as] the dominant trend of musical art at the 
turn of the XX and XXI centuries, which determines the foundations of the composer's "polyphony" era» [1, p. 36].

Invention by Valentyna Martyniuk was an attempt to create her own polyphonic works taking into account all the peculiarities and possibilities of the Ukrainian national instrument, which was followed by more detailed and large-scale cyclical polyphonic works.

Author's manner of V. Martyniuk attachment by a combination of different stylistic trends, attraction to theatricality, observance of folk traditions with their complete transformation in accordance with modern thinking. Incarnating deep authenticity, Valentina Martyniuk created her own, characteristic, individual style. The author does not limit herself to the method of citation, national intonation dictionary, but successfully combines traditional classical and romantic vocabulary, using variational techniques, counterpoint technique, brightness of unexpected tonal-fricative comparisons, timbre-register contrasts, techniques of modern compositional techniques - sonorists, polynomials, but etc.

In all polyphonic works $\mathrm{V}$. Martyniuk does not use her own themes, but exclusively themes of Ukrainian songs - authentic either folk or popular songs created by professional composers. S. Ovcharova notes: «Folklore and song basis of each work undoubtedly influences the creation of their own performance interpretation and universal material for the formation of artistic and figurative thinking of the bandura performer, whose main task is to develop a personal attitude to the author's composition...» [7, p. 5].

The themes of polyphonic works for bandura organically combine traditional counterpoint techniques and national song themes:

1. The Invention is based on the theme of the Ukrainian folk song «Oh, in the field, the room was a room»;

2. Chorale and fugues - romance by L. Alexandrov «I look at the sky» (Lyrics by M. Petrenko, arranged by V. Zaremba) and the Ukrainian folk song «Wolves went, oxen from the oak grove» (recorded in 2003 by O. Kandyba in the village of Chkalivka, Kryvyi Rih district, Dnipropetrovsk region);

3. Fuga and posthumans were based on Ukrainian folk songs «Oh, in the field, in the field there is a white stone» and «You deceived me»;

4. The prelude and fugue are based on the songs of P. Maiboroda «My Mother» (lyrics by A. Malyshko) and V. Vermenych «Chornobrivtsi» (lyrics by M. Singaivsky); 
5. Fantasy, fugue and epilogue - on the songs of V. Mykhailyuk «Cheremshyna» (lyrics by M. Yuriychuk), V. Ivasyuk «Waterfall»;

6. Fugue with Kolomyia and Four Inventions are written on the themes of Cossack songs of Dnipropetrovsk region.

Thus, in polyphonic works for bandura V. Martyniuk, who «used a number of traditional polyphonic genres for baroque music, which in their interpretation the composer marked, on the one hand, folklorization, on the other - the modernization of musical language» [5, p. 86], came to an organic synthesis of three components: the folklore basis as a sign of non-folklore, neo-baroque tendencies and introduced modern compositional techniques. This, in turn, applies to the whole state of modern music: "Polyphony of all aspects of the artistic whole led to the uniqueness of the processes of formation and individualization of the principles of musical drama, ultimately - the polystylistics of modern musical art» [6, p. 36].

One of the first polyphonic pieces for bandura in V. Martyniuk's creation was Invention. V. Martyniuk understands the genre of invention as an «intermediate» between prelude (fantasy, posthuman) and fugue, as if preparing the performer for the perception of the most complex polyphonic work. Based on the initial understanding of the word «invention» (Latin "fiction») as a small polyphonic play with various inventions on melody, principles of development, form, the composer combines in the invention different types of texture - polyphonic and homophonic.

The composition, construction and features of the development of the Invention V. Martyniuk determines the national song theme. It is based on the theme of the Ukrainian folk ballad «Oh, in the field, the field stood a room» ${ }^{1}$ :

A v tii svitlytsi Marusia lezhala.

A v tii svitlytsi Marusia lezhala.

Chornym shovkom holovu viazala.

The 4-bar theme is indicative of ancient songs:

- a small range in the volume of the fifth;

- the smoothness of the melodic movement with the filling of the initial jump on the fifth;

1 Українські народні пісні. Книга перша / упор. 3. Василенко та М. Гордійчук. Київ: Мистецтво, 1954. Р. 369. 
- flexible, typical for folklore size 5/4, which steals the metric accent and enhances the softness of the sound;

- a peculiar fricative color of the last cadence measure - «couplet» with Phrygian decoration. The value of the «couplet» measure is determined by its repeated repetition in the second, culminating section of the invention and at the end - the conclusion, where the cadence Phrygian inversion is given in double magnification.

The exposition section of the invention is similar to the exposition section of the fugue: the theme is held alternately in three voices viola, soprano and bass in tonic-dominant ratios. But the unrestrained opposition is a rather independent voice, which grows on the basis of the descending intonation of the theme (si-la-sol). Thus, the composer reproduces the undertone polyphony, which provides a folklore basis for the theme.

At the culmination, the polyphonic fabric yields to a tightly chordal movement, which, at the same time, counterpoints the theme in the bass provided in the quadruple magnification. Based on the tonal instability, the motivational development of the theme, this section can be considered free, concise in size, and a developing section of the invention. The last concentrated sound of the theme, together with the undertone in the initial e-moll, creates the arch of the whole play. As fading of dynamicsincrease in duration there is an impression of gradual removal of singing.

Work on the author's understanding of the genre of invention continued in a later opus - Four Inventions, which constitute a kind of cycle. Valentyna Martyniuk chooses urban folklore for him - Cossack songs of Dnipropetrovsk region.

It should be mentioned that the period of the Cossack era left a bright mark in the history of Ukraine on the way to becoming an independent and distinctive country. The role of the Cossacks and the Zaporizhzhya Sich is unique in the history of Ukraine and has no analogues in other nations. The Dnipropetrovsk region is considered the cradle of the Ukrainian Cossacks, as five of the eight Zaporizhzhya Sich were located on its territory. From here, according to Mykola Gogol, «the will and the Cossacks spilled over the whole of Ukraine».

Cossack songs, which originated in the fifteenth and sixteenth centuries with the advent of the Cossacks, are a quantitatively significant layer of 
Ukrainian folklore. Based on real historical facts and phenomena (struggle with Turkish-Tatar invaders, victories and defeats of the Cossack army, foreign captivity, captivity), Cossack songs primarily reproduce the lyrical image of the Cossack - a typical representative of the Zaporizhzhya Sich, his inner spiritual world and thoughts and fellings.

Cossack song is one of the oldest genre layers of household folklore. The theme, function and style of Cossack songs form a harmonious integrity, which distinguishes these works into a unique genre, an independent unit of Ukrainian songwriting. They unite a significant number of folklore works on social and everyday topics about life and campaigns, the difficult fate and life of the Ukrainian Cossacks in the conditions of the national liberation struggle of Ukraine. Cossack songs are marked by the richness of ideological content, emotional content, high art. At the same time, Cossack songs are one of the least studied arrays of Ukrainian folklore.

In 2015, the Cossack songs of Dnipropetrovsk region were included in the UNESCO World Intangible Heritage List, which needs urgent protection and support.

Research of musical folklore of Dnipropetrovsk region on the initiative of Yu. Novikov - rector of Dnipropetrovsk Academy of Music named after M. Glinka, started in October 2015 and continues to this day. To date, more than 50 settlements in nine districts of the region have been visited. Teachers of the academy, which study the folklore heritage of Dnipropetrovsk region (Pshenichkina G., Lyubimova A., Gusina O.), seek to capture, preserve and pass on to future generations a priceless national treasure that has developed over many centuries.

Four inventions on the themes of authentic, different in nature, Cossack songs of Dnipropetrovsk region are united not only by folklore origins. In the construction of the cycle there is a clear drama. You can identify the features of the actual cycle: all the pieces are small, about the same size, based on the undertone polyphony. Three of them are close to effective, marching Cossack songs as a kind of historical songs-dumas. They have the duality of the meter, active accent rhythms, dense dynamics of mf, $\mathrm{f}$, wide melodic jumps on the fifth-sixth.

The invention on the theme of the Ukrainian folk song «A Cossack stands on a black cliff» synthesizes the marching character defined by 
the author (Tempo di marcia) with the features of a lyrical Cossack song according to the content:

Stoit kozak na chornii kruchi,

V zadumi buina holova.

Riadom divchyna chornobrova,

$\mathrm{V}$ nei rozpletena kosa.

Povii viter, viter buinyi

Zainialos sertse vid zhaliu,

Bo kozak yide na chuzhbynu,

Lyshaie divchynu odnu.

triad, imitation of the theme in three voices is combined with variantsubvocal development. The composer retains the strict pure diatonicity of the theme, which sounds in the Phrygian style eg. Bach's invention does not take this form, although many of his inventions are saturated with elements of polyphonic composition (mostly imitations).

The invention on the theme "Songs about Nechay» is based on the People's Duma - a kind of lyrical and epic layer of national folklore:

Oi, z-za lisu, ta, oi, z-za lisu, z-za temnoho haiu

Oi kryknuly ta kozachenky: - Vtikaimo, Nechaiu!

- Ne biitesia, ne biitesia, pane otamane, -

Postavyv ya storozhenku usima shliakhamy.

Yak ya maiu, kozak Nechai, zvidsy utikaty,

Slavu svoiu kozatskuiu marno poteriaty.

A ya tebe, mii Nechaiu, ne ubezpechuiu.

Derzhy sebe konia v sidli dlia svoho zvychaiu!

This invention is of the grouted type. The monophonic four-bar theme is performed in all three voices with a gradual increase in dynamics, preserving the plagal tonal connections: h-e-h.

Both inventions end similarly to the decline in dynamics. There is a program idea in this - the march song seems to move away together with the Cossacks.

The invention of the Ukrainian folk song «Oh, in the field willow» represents a lyrical song. It is distinguished in the cycle of inventions by 
content, by meter (this is the only three-part song), by a freer variable size $(3 / 4,4 / 4$, in the original $-5 / 4,6 / 4,4 / 4)$.

Oi, u poli verba,

Pid verboiu voda.

Oi, tam divchyna vodu nabyrala

Khorosha, moloda.

$\mathrm{Na}$ dorizhechku hliadyt,

A dorizhechka kuryt.

Oi, tam yidut slavni kozachenky

Na koniakh voronykh.

The third invention is characterized by singing, greater proximity to folk performance. There is no «binding» to the fugue. Only the imitation introduction of voices reminds of a polyphonic idea. The support in the play becomes more vertical. Authentic material pushes the author to preserve the diatonic system, metric freedom with dimensional variability $3 / 4-{ }_{4 / 4}$, even elements of «prelude». At the end, like the first two inventions, the song is sung as if in a valley (meno mosso, rit., dim.).

The final invention on the theme of the Ukrainian Cossack historical song-duma «Maxim, Cossack Zaliznyak» is aimed at establishing vigor, energy, dance element:

Maksym, kozak Zalizniak, kozak z Zaporozhzhia -

Yak pryikhav na Vkrainu, yak povnaia rozha.

Zibrav viiska 40 tysiach v misti Zhabotyni.

Obstupyly horod Uman o vosmii hodyni.

The invention is more homophonic and harmonious in composition and is divided into squares - four bars, like verses of a song. Unlike the previous three inventions, the final invention ( $\mathrm{G}$ major) ends in a life-affirming, loud, persistent, Picardian third of the parallel minor. Thus a clear tonal and even genre drama of the cycle «Four Inventions» is built: from the march $(\mathrm{e}, \mathrm{h})$ through the song $(\mathrm{g})$ to the dance (G-e-E).

\section{Polyphonic baroque cycles for bandura}

V. Martyniuk, in general, prefers polyphonic cycles, which have identified new types of instrumental-polyphonic diptych. An important 
role in them is given to the problem of the unity of cycles, as well as an innovative approach to the distribution of their components: Finally, there is a three-part cycle - Fantasy, Fugue and Epilogue.

As is well known, the two-part polyphonic diptych «prelude-fugue», which derives from Baroque organ works by D. Frescobaldi, I. Pachelbel, D. Buxtehude and reached the highest perfect level in I. Bach, is one of the most established small cycles. This can be explained by the contrast of images embedded in it, the combination in the prelude with the fugue of two principles - homophonic and polyphonic, the principles of improvisational and logically sound constructions.

M. Dremlyuga was the first, who turned to the small baroque polyphonic cycle for bandura, creating the Prelude and Fugue in collaboration with S. Bashtan.

The clearly defined national-song theme distinguishes Martyniuk's polyphonic works and distinguishes them from traditional polyphonic cycles. At the same time, the organic combination of the academic form of the fugue with national origins allows us to consider these works in terms of European tradition.

Choral and Fugue - V. Martyniuk's first appeal to the polyphonic cycle for bandura. It naturally combines the folklore of the origins, the classical principles of thematic development, first of all, in the fugue, taking into account the peculiarities of playing the bandura. The contrasting form is reinterpreted because the fusion is preceded by a chorus, not a prelude or toccata; there is no tempo contrast between the components of the diptych cycle; Ukrainian song themes are the basis of both chorales and fugues.

The author used the well-known Ukrainian song «I look at the sky» for the theme of the chorale, which gained the status of a folk song (music by L. Alexandrova, lyrics by M. Petrenko, arrangement by V. Zaremba). The composer embodied the tragic lyrics of the song unexpectedly unconventionally: there is no tact and full theme, in the chord movement in the chromatic e-moll with the bell bass «e» only the contours of the theme are preserved. Due to the unusual harmonies, the song acquires a sublime, alienated and mournful sound in the choir.

The form of the Choral is similar to the verse-strophic structure inherent in a song with elements of variational development. Note the thematic concentration of the work, as both three verses and «choruses» are based on 
the intonations of the main theme. This determines the continuity, flexibility of musical development. Despite the tonal isolation and completeness of the Choral, there is a continuity, the need for further musical action that takes place in the fugue.

The theme of the three-part fugue is perceived as a supposed continuation of the Choral. Both parts are connected by one e-moll key, which is typical for small baroque cycles. But not typical is the only slow tempo of the chorus and fugue, the nature of the sound and the general genre-song basis. In addition, both themes, which form the basis of the polyphonic cycle, belong to one variety - lyrical romance song.

For the theme of the fugue V. Martyniuk used a part of the Ukrainian folk lyrical song of the Black Sea Cossacks «Wolves went, oxen from the oak grove»:

Ishly voly, voly iz dibrovy, a ovechky z polia.

Rozmovliala moloda divchyna z kozachenkom stoia.

Kudy idesh, kudy vidizhdzhaiesh, syzokrylyi orel.

A khto zh mene - molodu divchynu, $\mathrm{v}$ tsei vechir pryhorne?

The composer kept the presentation of the original: the first two bars of the theme are like a unanimous chant, the next two bars add sonority, duplicating the theme in thirds. Which is not typical for themes of classical fugues. The real answer is in the upper voice, in the key of h-moll, corresponding to the traditional for the fugue tonal patterns. The contrasting, which grows from the intonations of the theme - the descending tetrachord acquires sufficient relief and expressiveness, which creates the similarity of a real undertone.

The first interlude, before the introduction of the third voice, is based on the intonations of the complication with a characteristic movement on the descending tetrachord. The second answer - conducting the theme in the bass in the main key of e-moll in a compacted three-part texture on the dynamics of forte becomes its dynamic version.

The free part of the fugue is based on the motive fragmentation of the theme, sequences, changes of order, rococo and treatment. The dynamic reprise translates the theme from minor to $\mathrm{E}$ major (E major). This final section is shorter than the previous ones, but it contains the culmination of the fugue. In the bass voice, the theme is in the increase, and in the upper - 
in the address. With 79 volumes, the theme is performed entirely in chord, but instead of the last sound of the theme there is an ellipse - sf is suddenly invaded by an expression-filled chord in C minor. On the pp, which enhances the dramatic mood, the chorus beats, reminiscent of the beginning of the cycle and intonationally connecting the clear form of the work. The final bars of the work are a dynamic version of the previous ones, but enhanced by the chord texture, and effectively, arpeggio, are resolved into the final tonic septachord.

This principle of composition, integrated into the merging of academic, canonical polyphonic techniques with a national basis, confirms the words of the researcher of the Ukrainian polyphonic school S. Miroshnychenko: «Based on the technique of imitation polyphony, the composer subtly combines it with the folklore nature of the melodic cells that form the canon. Thus, contrapuntally combined layers form a complex saturated vertical and at the same time reveal the constructiveness of the pure color of quarto-fifth sounds, specific to the intonation dictionary of Ukrainian melody» [6, p. 139].

Prelude and Fugue - the only polyphonic diptych V. Martyniuk, which preserves the established coincidence of regulated works. But even in it the composer does not deviate from his creative credo and bases his Ukrainian song theme. This time the author chooses not authentic, but author's songs, which gained great fame, popularity and became really folk: «Song of the towel» by P. Maiboroda and «Chornobrivtsi» by V. Vermenych.

Prelude and Fugue - one of the most compact two-part cycle V. Martyniuk. Both parts are united by palmar (d-moll), lyricism of the songs underlying - «Song of the Towel» and «Marigolds», similarity of the initial intonation $(a-g-a-f)$, as well as their final chord in the form of «complex tonic» - tonic septachord with the sixth of the eponymous major.

The Prelude consists of two sections, representing variants of the initial intonation of «Songs about a towel». The composer veils the intonation of a familiar song in the rhythmic equality of the sixteenth, creating the effect of «hidden polyphony». And naturally dissolving the topic in further free development. The bass complements and updates the song theme with an additional counterpoint.

The second section of the prelude switches the theme to another rhythmic movement by the eighth. The first part of the polyphonic diptych is completed by a free-improvised section, which resembles an introduction and forms the resemblance of an arch. 
The three-part fugue is constructed in such a way that the first half of the song's verse (the words "Chornobryvtsi sowed mother») is its fourbar theme. Counter-composition grows from the title intonation of the theme and, developing it, becomes ostensibly its new variant-undertone, keeping the inherent dimension, clear simple rhythm, sequential principle. The second half of the verse - a kind of chant (the words «How to look at those marigolds») becomes the basis of the interlude, which logically continues the answer. A kind of postscript, the last point is perceived chordal dense reminder of the original motif of the theme.

In the Fusion V. Martyniuk combined different types of polyphony: contrast (chant-chorus), imitation and chord with free connection of additional voices in the climactic sections.

Valentina Martyniuk's Fugue and posthuman can be considered as an example of addressing the posthuman in the context of a small polyphonic («neo-baroque») cycle. The three-part fugue is based on the Ukrainian folk lyric song «Oh, in the field, in the field there is a white stone», in the posthuman there is a tangible allusion to the humorous dance song «You deceived me».

The genre of posthuman (from Latin - post, «next game») has received ambiguous interpretations. It was originally formed in medieval organ music as the play's finale. In the Baroque era, posthumans were called instrumental endings of vocal works that were of independent artistic interest. Examples of independent posthumans of the Baroque era are rare. This is the Postlude for F major in Johann Caspar Fischer, 1679. The Postlude becomes part of a polyphonic cycle: Prelude, Fugue and Postlude for G minor by George Bem, 1698 (Volume I of the complete collection «Free works for piano and organ»).

The renewal of interest in the posthuman is manifested in the era of romanticism. Independent posthumans write: Gustav Merkel (10 Vopund Nachspiele op. 134), Oscar Maricante (Postlude op. 88 № 2), William Thomas Best («Christmas Posthuman»). From the twentieth century begins a wide appeal to the posthuman (cycle «24 posthumans» by Leonid Polovinkin, 1938).

The period of the end of the XX - beginning of the XXI centuries is saturated with many examples of isolated posthumans who became «universals of the genre» (statement of M. Kuznetsova). Postludes are intended for any instruments. For the piano posthumans were written by 
Andrea Ferrante (Postludio a un Sogno), Faraday Karaev (11 versions for different instruments), Alfred Schnittke, Witold Lutoslawski; for cello, violin solo by Dmitry Smirnov (Postlude in memory of Alfred Schnittke); for orchestra - Sergey Plekhanov (Postlude for guitar with orchestra), Eduard Artemyev (Postlude from the movie «Tired of the Sun...», Edison Denisov (Postlude for orchestra in memory of Vitold Lyutoslavsky), Yuri Kasparov for the post; for orchestra for piano, double bass and string quartet, for clarinet, piano and violin, viola and cello on stage, for piano, string orchestra and choir on stage, for piano, vibraphone and string quartet on stage).

The postlude is also interpreted as an integral, final part of large-scale works; as in the Baroque period, it finds a place in cyclical compositions (Alfred Schnittke's Concerto grosso), including in polyphonic cycles («Prelude, Fugue and Posthumous» by Leo Solin, «Ludus tonalis» by Paul Hindemith).

The postlude is gradually established as a self-sufficient musical genre and is saturated with its own figurative meanings, connected with the sphere of comprehension, reaction, reflection, memories. According to M. Kuznetsova, each work becomes «an afterword of a certain epoch, tradition, and style» [4, p. 1].

In Ukrainian music, posthumans acquire special significance thanks to the creative interests of Valentin Silvestrov: in addition to chamber works - DSCH Postlude for soprano, violin, cello and piano, the composer creates major posthumans - Fifth Symphony and Postlude for piano and chamber music.

For Valentina Martyniuk, the posthuman becomes a kind of mirror image of a virtual prelude. Due to the absence of the latter, the posthuman with its improvisational texture is typical of the prelude nature and free form partially assumes its functions. According to its scale, a type of development that contains several sections, the posthuman can be interpreted as a fantasy.

The unity of the cycle Fugue and posthuman, as well as Choral and fugue, is ensured by the tonal unity of its components (e-moll) and tempo proximity (Andante-Largo). The theme of the fugue is expanded, which is subordinated to the volume of the 8-bar theme of the folk song:

Oi u poli, v poli bil kamin lezhyt, A na tomu kamenevi syz orel sydyt. 
Oi sydyt zhe vin, sydyt, dumku hadaie,

Yde kozak z Ukrainy, orla pytaie:

- Chy buv ty, syzyi orle, v moii storoni,

A chy tuzhyt moia myla teper po meni?

- Tuzhyt, tuzhyt, tuzhyt i v lizhku lezhyt,

A pravoiu rukoiu za sertse sia derzhyt.

The counter-composition is based on the key intonation of the song its descending tetrachord. This provides intonation commonality and corresponds to a purely folk type of undertone polyphony. The first interlude with imitative echoes of voices, which precedes the bass performance of the theme, is built on the same intonation of the descending tetrachord. The free part of the fugue, prepared by an interlude with modulating motion a-C-f, is divided, like the main theme, into 8 bars. And the stage changes the undertone-imitation texture to a homophonic one with a leading theme in the bass and accompanied by three upper voices with a condensed, chordinterval sound.

The next stage is the general culmination of the fugue, more precisely, its culmination zone. Its onset is being prepared, «maturing» in a 4-stroke predicate-type relationship with a gradual increase in dynamics and slowing down. The climax is not only the highest dynamic level (ff). It concentrates the main thematic core in a sharply dissonant, harmoniously rigid form. The tension is added by the tessitural distance between the voices - the «theme» in the bass (high octave) and the tape triad of the upper voices (third or second octave).

The third stage of the free part of the fugue includes a plagal performance of the theme and a reprise section, defined by the return of the main key of e-moll with the replacement of the eponymous E-major and song theme in a variationally modified form.

The bass tonic sound connects the end of the fugue with the beginning of the posthuman. For all the freedom, the fantasy of the texture of the posthuman, the initial sounds of the fugue theme $(e-e-g-f i s-e)$ are intertwined in the context of its fabric. This intonation unity, which is not typical for small polyphonic cycles, emphasizes the relief of the leading song intonation and creates a strong knot of both sections of the cycle, inseparable from each other. 
The postlude unfolds quite widely, on a grand scale, turning into a purely concert, virtuoso play. The first section of the posthuman (Largo) is a kind of «preamble». The second section (Moderato) is built on a clearly tangible thematic basis - allusions to the song «You fooled me», which is held in the bass register in the increase against the background of a continuous search of the sixteenth in the upper voice.

The intonations of the theme reveal the closeness to the theme of the fugue (the song «Oh, in the field, in the field the white stone lies»), so the theme of the posthuman is perceived as a variant of the theme of the fugue. In such intonation drama of the work it is possible to find a real symphony, like «Kamarinskaya» by M. Glinka.

The third section - the largest, of a developmental nature, with frequent tonal switches: e-c-h-Es-c - leads to a climax. The last section is a dynamic reprise of the leading theme of the posthuman. Bright, loud (ff), wide, major, with the effect of the Picardian third, the play ends.

Fugue and Kolomyia continues the line of V. Martyniuk, which began in Fuza and the posthumans. The two-part cycle opens not with a homophonic play, but with a fugue based on the song «Oh, for the current, the current» [3, p. 15]:

Oi, za tokom, tokom

Stoit divka z kozakom.

Stoit divka z kozakom.

Zakrylasia rukavom.

Zakrylasia oboma

Vin tsiluie obnima.

Kokhanoiu nazyva.

Ta y za rosy zasyla.

The initial presentation of the theme of the song is not unanimous. It is supported by bass and, in addition, the sounds of middle voices. V. Martyniuk departs from the classical structure of the fugue. This time the fugue is quite free and more reminiscent of choral folk singing. After the second holding of the theme in the middle voice, all further movement is variants-undertones of the main theme. It is possible to single out only the beginning of the free part of the fugue due to the ascent to other tones and, conditionally, a dynamic reprise section, where the theme sounds in the bass 
almost in its original form. This is the culmination of the fugue. The last 10 bars slow down the tempo, «blur» a clear size $4 / 4$ with a variability of $5 / 4$, 3/4, 4/4, harmonious sharpness and tartness.

Fugue is combined with kolomyyka attacca principle. At first glance, the theme of kolomyyka is perceived as author's, but, in fact, it is a rhythmically sharpened, transformed version of the theme of the fugue. Thus, Fugue and Kolomyia is the only polyphonic cycle by V. Martyniuk, which is built on the basis of one theme. Thanks to the genre transformation, the composer creates a bright, impressive contrast between the parts of the cycle - lyrical fugue and dance Kolomyia.

The latter explodes at a fast pace, syncopated rhythm, color. The picture of the Igutsul party is framed by imitations of the sound of a drum. The author emphasizes in his Kolomyia - the traditional genre of Ukrainian folk music and choreography, the most popular in Western Ukraine - the typical features of dance song: motor skills, humorous content, fast pace, duality, improvisation, «exclamations» (accents, imitation calls) instruments: violin, bass, drum, cymbals. Rhythmic transformation is limited to purely performing techniques: expansion, compression of rhythm, the appearance of punctuation, trios, free tempo [2, p. 214-218].

Fantasy, fugue and epilogue - the only three-part polyphonic cycle of V. Martyniuk. It is the largest and most complex for the performer, first of all, by its structure and drama. The whole cycle is quite monolithic. Both song themes, which form the basis of the three-part cycle - «Cheremshina» and «Vodogray» - have rhythmic and fricative intonation.

Fantasy is thematically combined with the epilogue: fantasy - section Allegro, rubato, epilogue - Lento. The fugue and the epilogue are based on one intonation source - V. Ivasyuk's songs «Vodogray» and are connected by the principle of attacca. Tonal logic strengthens the unity of the triptych: d-moll Fantasies and fugues with modulation in parallel h-moll of the same name in D major; d-moll epilogue with reverse modulation into the initial d-moll. Fantasy is connected with a fugue by harmonious relations. Open to an authentic half-cadence, the fantasy precedes the beginning of the fugue like the attacca reception. In addition, fantasy and the epilogue, which actually becomes posthuman, bring together the genre nature, unique in its free structure, improvisational texture. She refers to the prelude as the original source. 
All three components of the cycle are written in one predominant meter and size $6 / 8(12 / 8,9 / 8)$, only in some unstable areas in freer pieces - fantasy, epilogue - there is a variability of meter and size.

The drama of the whole work is purposeful from the lyrical confession of fantasy through gradual enlightenment, raising the mood through the haze of memories to genre changes in the fugue - dancing at the beginning (accents, syncope, staccato), lyrical beginning. Gradual injection leads to the climax, holding the theme in the bass leaves a feeling of energy, determination.

The epilogue (Grave) sounds almost tragic. It's like a burst of bitterness. The sound dissolves, melts, through pain, tragedy, struggle, the state of childhood memories returns, bright images of motherhood, pictures of nature, the last bars - the major end, the hope for a bright future.

\section{Conclusions}

The creative preferences of the composer Valentina Martyniuk in the 2000 s testify to a purposeful interest in the original capabilities of the bandura. Composing numerous works of various genres, starting with traditional solo songs, the composer came to the need to create an original achievement in purely instrumental genres - solo and ensemble, where the bandura timbre was combined with other «classical-academic» and «national» instruments.

The next stage - the manifestation of purely solo bandura features - fell on the assimilation of polyphonic forms, genres, techniques of composition. The appeal to the original «bandura polyphony» proved not only the ability to combine national melody with its features, which stemmed from the targeted reliance on song material as the basis of all but exclusively polyphonic works, but also the fact that famous polyphonic genres received new life.

First of all, V. Martyniuk updated the idea of models of a small baroque polyphonic cycle in the form of either a diptych (Fugue and Postman, Choral and Fugue, Prelude and Fugue, Fugue and Kolomyia), or a triptych (Fantasy, Fugue and Epilogue). This applies to the understanding of form, drama of cycles based on artistic design, and the use of combined means of expression, again in a combination of academic and purely national. 
Each new polyphonic opus of Valentina Martyniuk offers new techniques, new possibilities of the instrument. The very fact of selecting song material for his plays testifies to the interest in learning and studying the variety of Ukrainian folklore, which is united by the name «Cossack songs» and has become the center of attention of the world cultural community in recent years.

\section{References:}

1. Cossack songs of Dnipropetrovsk region / order. Glinka Dnepropetrovsk Conservatory; front the word E. Udod (2015). Dnipropetrovsk: Lizunov Pres, 60 p.

2. Ivanitsky A. (2004). Ukrainian musical folklore. Kiev: Nova book, pp. 214-218.

3. Kuznetsova M. (2010). Postlude by V. Silvestrov: poetics and semantics of the genre. Muzyikalnaya akademiya, vol. 4, pp. 129-135.

4. Lisnyak Inna (2019). Academic Bandura Mistetstvo of Ukraine Kintsya XX - the cob of the XXI century / [goals. ed. G. Skrypnik]. Monograph. Kiev: IMФE named after M. Rylsky NAS of Ukraine, $254 \mathrm{p}$.

5. Miroshnichenko S. (2012). Polyphonology as a musicological discipline and the national nature of Ukrainian polyphonic music. Odessa: Astroprint, $296 \mathrm{p}$.

6. Ovcharova S. (2017). Ukrainian song in polyphonic works for bandura: performing aspect. Ukrainian song in polyphonic works for bandura. Tutorial. Dnipro: LIRA, 68 p.

7. Zavgorodnyaya G. (2012). Polyphonic foundations of modern composer creativity. Analytical essays. Monograph. Odessa: Astroprint, 304 p. 